\title{
Profil Pembelajaran Suhu dan Kalor di SMA Se-Kabupaten Keerom
}

\author{
Indah Slamet Budiarti, Suparmi, Cari, Sarwanto, Harjana \\ Universitas Negeri Sebelas Maret Surakarta \\ J1. Ir. Sutami 36A Jebres Surakarta \\ Surat-e: indah_budiarti@student.uns.ac.id
}

\begin{abstract}
Pembelajaran melibatkan tiga aspek yaitu kognitif, psikomotor, dan afektif. Penelitiaan ini bertujuan untuk mendeskripsikan pembelajaran suhu dan kalor di SMA se-Kabupaten Keerom. Penelitian ini merupakan penelitian deskriptif. Sampel diambil menggunakan teknik purposive random sampling, yang terdiri dari tiga SMA di Kabupaten Keerom. Data diperoleh melalui pengamatan di kelas dan wawancara secara mendalam pada guru yang mengajar pada materi suhu dan kalor. Berdasarkan data dan analisis, hasil penelitian ini menunjukan bahwa pembelajaran suhu dan kalor di SMA se kabupaten Keerom belum sesuai dengan hakekat pembelajaran sains dimana tidak semua guru menerapkan model pembelajaran berbasis pada siswa. Hanya satu SMA yang menggunakan model pembelajaran yang berbasis pada siswa yaitu menggunakan model pembelajaran kooperatif dengan metode demostrasi, walaupun masih terdapat kelemahan pada proses pembelajarannya yaitu hanya beberapa siswa yang aktif dalam pembelajaran.
\end{abstract}

Learning involves three aspects: cognitive, psychomotor, and affective. This research aims to describe the learning of the subject: temperature and heat in the Keerom regency high school. This research is a descriptive research. The sample was taken using purposive random sampling technique, which consisted of three High Schools in Keerom Regency. Data were obtained through in-class observation and in-depth interviews on teachers who taught on temperature and heat subject. Based on the data and analysis, the results of this study shows that learning temperature and heat in high school in Keerom regency is not in accordance with the nature of science learning where not all teachers apply learning models based on students. Only one high school using a learning model based on students is using cooperative learning model with demostration method, although there is still a weakness in the learning process that is only some students who are active in learning.

Kata kunci: Pembelajaran, Sains, Suhu dan Kalor

\section{Pendahuluan}

Perkembangan ilmu pengetahuan yang sangat pesat pada abad ini berdampak pada masyarakat luas termasuk masyarakat di Indonesia, tidak terkecuali pada dunia pendidikan. Berdasarkan perkembangan ilmu pengetahuan, maka perlu dilakukan reformasi dalam dunia pendidikan, termasuk strategi pembelajaran yang dilakukan guru di dalam kelas. Kurikulum di Indonesia berubah seiring berkembangnya ilmu pengetahuan. Papua merupakan propinsi paling timur di wilayah Indonesia. Karena kendala letak geografis, maka Papua terlambat dalam mengikuti perkembangan kurikulum. Pada saat ini, di Papua sedang dilaksanakan kurikulum 20I3, walaupun tidak semua sekolah sudah melaksanakannya karena terbentur dengan beberapa faktor, diantaranya letak geografis, sumber daya manusia (guru), dan sarana serta prasarana sekolah.

Fisika merupakan bagian dari IPA (sains), dimana sains merupakan cabang ilmu yang focus pengkajiannya adalah alam dan proses yang ada didalamnya. Menurut BNSP (2006), sains bukan hanya sekedar kumpulan dari fakta, konsep, prinsip saja, melainkan proses penemuannya. Menurut Khalick et.al[I], hakikat sains merupakan pengetahuan tentang metode dari sains, proses terjadinya sains, atau nilai dan keyakinan untuk mengembangkan sains. Hakikat dari ilmu sains adalah penemuan, yang meliputi produk, proses, dan sikap. Pembelajaran sains sebaiknya menekankan pada proses, dimana siswa aktif membangun pengetahuannya dalam serangkaian kegiantan pembelajaran, sehingga pembelajaran menjadi bermakna 
bagi siswa. Menurut Kubicek[2], pendidikan sains diarahkan pada inkuiri, dimana siswa terlibat langsung, dan memperoleh pemahaman yang lebih mendalam tentang alam sekitar.

\section{Metode Penelitian}

Metode penelitian yang digunakan dalam penelitian ini adalah deskriptif, yang cocok untuk mendeskripsikan pembelajaran suhu dan kalor di SMA. Sampel diambil menggunakan purposive random sampling yang terdiri dari 3 Sekolah Menengah Atas di Kabupaten Keerom : SMAN I Arso, SMA YPPK Taruna Tagasa, dan SMA Al Mutakim. Data diperoleh melalui pengamatan di kelas dan wawancara mendalam pada guru yang mengajar pada materi suhu dan kalor. Pedoman wawancara digunakan untuk menggali informasi lebih lanjut tentang pembelajaran yang dilaksanakan oleh guru, dengan indikator: kesulitan yang dihadapi oleh guru saat mengajar, model dan metode pembelajaran yang digunakan oleh guru, frekuensi dalam melakukan praktikum fisika selama I semester, dan bahan ajar/modul yang digunakan oleh guru dan siswa.

\section{Hasil Penelitian dan Pembahasan}

Hasil penelitian yang diperoleh melalui pengamatan di kelas dan wawancara mendalam pada guru yang mengajar pada materi suhu dan kalor. Pembelajaran fisika sangat erat kaitannya dengan proses penemuan, dimana siswa terlibat aktif memperoleh pengetahuan dalam proses kegiatan pembelajaran.

Berdasarkan pengamatan di kelas, hanya I guru dari 3 guru yang mengajar materi suhu dan kalor dengan model pembelajaran kooperatif, dan metode demonstrasi. Guru tersebut membagi siswa dalam 5 kelompok. Guru menyiapkan alat dan bahan seperti, termometer, gelas ukur, kalorimeter, air panas dan air dingin. Guru yang melakukan demonstrasi di dalam kelas, cara melakukan pengukuran suhu dengan menggunakan termometer, dan cara menggunakan kalorimeter untuk mengukur suhu campuran. Kelemahan yang dilakukan guru dalam proses pembelajaran adalah jumlah siswa di dalam kelompok masih terlalu banyak, guru belum menggunakan Lembar Kerja Siswa yang mengajak siswa untuk menemukan konsep, guru yang aktif melakukan demosntrasi, hanya ketua kelompok yang aktif dalam proses pembelajaran. Siswa mengalami kesulitan pada konsep Asas Black dan perpindahan kalor. Menurut Sozbilir[3] konsep suhu dan kalor yang terlalu abstrak menimbulkan berbagai pemikiran yang berbeda pada siswa ketika mempelajarinya. Thomas et al[4] menemukan bahwa siswa memiliki kesulitan yang tinggi untuk menerima bahwa benda yang berbeda akan memiliki suhu yang sama ketika disentuhkan pada lingkungan yang sama selama beberapa waktu. Hal ini sejalan dengan penelitian yang telah dilakukan oleh Baser[5], bahwa siswa kesulitan dalam memecahkan masalah perpindahan kalor secara konduksi pada seat belt, dimana seat belt terdiri dari logam dan non logam.

Materi suhu dan kalor merupakan materi fisika yang erat kaitannya dengan fenomena alam ataupun kehidupan sehari-hari, sehingga seharusnya siswa lebih mudah untuk membangun pengetahuannya jika guru menerapkan model dan metode pembelajaran dengan tepat. Dengan demikian, siswa belum memperoleh gagasan, keterampilan dari model pembelajaran yang digunakan oleh guru. Hal ini tidak sesuai dengan pendapat Joyce, et.al[6], dimana model pembelajaran adalah cara untuk membantu siswa memperoleh informasi, gagasan, skills, nilai, cara berpikir, dan mengekspresikan diri. Sebenarnya model pembelajaran kooperatif merupakan model pembelajaran berbasis konstruktivisme, dimana siswa membangun pengetahuan di dalam proses pembelajaran. Kekuatan teori belajar konstruktivime adalah pembelajar mampu menafsirkan realitas-realitas ganda, pembelajar menjadi mampu dengan lebih baik menghadapi situasi kehidupan nyata. Jika seorang pembelajar bisa menyelesaikan masalah, mereka mungkin menggunakan pengetahuan yang mereka punyai dengan lebih baik bagi sebuah situasi baru. Oleh karena itu, pentingnya model pembelajaran yang sesuai dengan karakteristik materi ajar.

Sedangkan 2 guru lainnya, mengajar materi suhu dan kalor dengan metode ceramah. Guru mengajar tanpa menggunakan alat peraga ataupun praktikum. Menurut Sozbilir, materi suhu dan kalor merupakan materi yang abstrak. Dengan demikian, guru tidak mencoba untuk mengkonkretkan materi suhu dan kalor. Keuntungan dari 2 SMA tersebut, khususnya SMA Al Mutakim, jumlah siswanya hanya II orang, sehingga proses pembelajaran siswa kondusif, dimana guru dengan mudah memonitor siswa di dalam kelas. Semua materi suhu dan kalor, baik suhu, kalor, asas black, dan perpindahan kalor disampaikan oleh guru dengan metode ceramah, sehingga siswa menjadi bosan, dan mereka sibuk dengan menulis di buku, tapi tidak paham apa yang mereka tulis. Pembelajaran sains meliputi tiga aspek, yaitu: kognitif, psikomotor, dan afektif. Jadi sebaiknya di dalam proses pembelajaran, guru tidak hanya menekankan pada aspek kognitif saja, tapi aspek psikomotor dan afektif juga diperhatikan. Aspek psikomotor dan afektif bisa diperoleh pada saat siswa melakukan eksperimen atau praktikum.

Berdasarkan wawancara yang mendalam pada tiga guru di SMA Kabupaten Keerom dapat dilihat pada tabel I. 
Tabel I. Analisis Pembelajaran Suhu dan kalor di SMA

\begin{tabular}{|c|c|c|}
\hline No & Aspek Wawancara & Masalah \\
\hline $\mathrm{I}$ & $\begin{array}{l}\text { Kesulitan yang dihadapi } \\
\text { oleh guru saat mengajar }\end{array}$ & $\begin{array}{l}\text { Kemampuan awal siswa } \\
\text { rendah. Sebagian besar siswa } \\
\text { mengalami kesulitan dalam } \\
\text { menyelesaikan soal secara } \\
\text { matematis. Siswa kesulitan di } \\
\text { dalam memahami konsep. } \\
\text { Siswa kurang termotivasi } \\
\text { dalam belajar fisika }\end{array}$ \\
\hline 2 & $\begin{array}{l}\text { Model dan metode } \\
\text { pembelajaran yang } \\
\text { digunakan oleh guru }\end{array}$ & $\begin{array}{l}2 \quad \text { guru dari } 3 \text { guru } \\
\text { menyatakan bahwa mereka } \\
\text { menggunakan } \\
\begin{array}{l}\text { ceramah } \\
\text { metode }\end{array}\end{array}$ \\
\hline 3 & $\begin{array}{l}\text { Frekuensi melakukan } \\
\text { praktikum fisika dalam } \\
\text { I semester }\end{array}$ & $\begin{array}{l}\text { I sampai } 2 \text { kali dalam } \\
\text { semester, dengan alasan tidak } \\
\text { adanya alat-alat laboratorium } \\
\text { yang memadai. Praktikum } \\
\text { yang dilakukan tidak } \\
\text { menggunakan metode } \\
\text { eksperimen, dimana siswa } \\
\text { aktif di dalam kelompoknya, } \\
\text { tetapi guru menggunakan } \\
\text { metode demonstrasi, dengan } \\
\text { menyesuaikan alat-alat di } \\
\text { laboratorium dengan materi } \\
\text { ajar. }\end{array}$ \\
\hline 4 & $\begin{array}{l}\text { Buku ajar/modul yang } \\
\text { digunakan siswa }\end{array}$ & $\begin{array}{l}\text { Guru mempunyai lebih dari } \\
\text { I buku ajar, tapi untuk siswa } \\
\text { hanya mempunyai LKS dari } \\
\text { salah satu penerbit yang } \\
\text { isinya hanya rangkuman } \\
\text { materi dan soal-soal. }\end{array}$ \\
\hline
\end{tabular}

Berdasarkan hasil wawancara pada tabel I, pada aspek wawancara yang pertama, ketiga guru menyatakan hal yang sama yaitu bahwa kemampuan awal siswa rendah, sebagian besar siswa mengalami kesulitan dalam menyelesaikan soal secara matematis, siswa kesulitan di dalam memahami konsep, dan siswa kurang termotivasi dalam belajar fisika. Hal ini menunjukkan bahwa masalah input menjadi persoalan utama guru. Jadi seharusnya guru membuat strategi di dalam menyampaikan materi ajar sehingga siswa dapat memahami materi ajar dengan baik, dan masalah input siswa dapat terselesaikan.

Berdasarkan hasil wawancara pada aspek wawancara yang kedua adalah, dua guru dari tiga guru menyampaikan bahwa dalam mengajar materi suhu dan kalor, mereka menggunakan metode ceramah, yang artinya bahwa model pembelajaran yang digunakan berpusat pada guru. Mereka beralasan bahwa hanya metode pembelajaran ceramah yang dapat digunakan untuk menyelesaikan materi berdasarkan tuntutan kurikulum. Selain itu metode ceramah juga mudah dilakukan dengan tanpa persiapan yang lama atau membutuhkan biaya.

Berdasarkan hasil wawancara pada aspek wawancara yang ketiga adalah hanya satu sekolah yang melakukan eksperimen atau demonstrasi sebanyak 2 kali dalam satu semester, termasuk di dalamnya demonstrasi suhu dan kalor. Dua guru yang lainnya menyatakan bahwa hanya satu kali dalam satu semester, mereka melakukan demonstrasi, dan materi suhu dan kalor tidak termasuk di dalamnya.

\section{Kesimpulan}

Jadi berdasarkan hasil pengamatan di kelas dan wawancara mendalam pada guru, dapat disimpulkan bahwa pembelajaran suhu dan kalor di SMA se-kabupaten Keerom belum sesuai dengan hakekat pembelajaran sains dimana tidak semua guru menerapkan model pembelajaran berbasis pada siswa. Hanya satu SMA yang menggunakan model pembelajaran yang berbasis pada siswa yaitu menggunakan model pembelajaran kooperatif dengan metode demostrasi, walaupun masih terdapat kelemahan pada proses pembelajarannya yaitu hanya beberapa siswa yang aktif dalam pembelajaran.

\section{Kepustakaan}

[I] Khalick, Abd-El, Fouad, Lederman,N.G., Bell, Randy.L. I998. The Nature of Science and Instructional Practice: Making the Unnatural Natural.Science Education, 82: 417-436.

[2] Kubicek, J. P. 2005. Inquiry based learning, the nature of science, and computer technology: New possibilities in science education. Canadian Journal of Learning and Technology. 3I(I). I-7

[3] Sozbilir, Mustofa. 2003. A Review Of Selected Literature On Student's Misconception Of Heat And Temperature. Journal of Education Vol. $20(1)$

[4] Thomas, M. F. Malaquis et all. 1995. An Attempt to Overcome Alternative Conception Related to Heat and Temperature. Physics Education. 30, 19-26

[5] Baser, Mustafa. 2006. Effect of Conceptual Change Oriented Instruction on Students' Understanding of heat and Temperature Concept. Journal of Maltese Education Research, (On-line), 4(I): 64-79

[6] Joyce, B., weil, M., \& Calhoun, E. 20II. Model of Teaching $\left(8^{\text {nd }}\right.$ Edition). Diterjemahkan oleh ahmad Fawaid dan Ateilla mirza. Model-Model Pengajaran. Yogyakarta : Pustaka Pelajar 